\title{
WITHOUT A COMPASS: SALONIKAN JEWS IN NAZI CONCENTRATION CAMPS AND LATER
}

\begin{abstract}
During the Holocaust, the largest Sephardi community in the world located in Saloniki was almost completely destroyed. Despite their limited number in comparison with that of Ashkenazi Jews, the Salonikan Jews, initially deported to Auschwitz Birkenau and Bergen Belsen, went through all the hardest experiences and were sent to many camps in occupied Poland, and in Germany. This article explores, using archival documents and the testimonies, the geographical directions of their deportations. It also analyses historical coordinates and the Salonikan Jews' characteristics which affected their destinations and the itinerary with which they were forced to cope.

Key words: Holocaust, deportations, Sephardim, Saloniki, concentration and extermination camps, slave labour, language, testimonies, displaced persons' camps.
\end{abstract}

\section{INTRODUCTION}

The Community in Saloniki was the largest Sephardi community in the world before 1943. About 60,000 Jews used to live in the city, commonly known as the Jerusalem of the Balkans: their ancestors at the end of the 15th century had moved there, then part of the Ottoman Empire, as a consequence of the expulsion of Jews from Spain (Sepharad).

For five centuries the Jewish presence had been shaping the features of the city, where it constituted the majority of the population until the first two decades of

\footnotetext{
* Stefania ZEZZA, Former Tutor at International Master on Holocaust Studies Roma Tre, President of Etnhos (European Teachers Network on Holocaust Studies), Via Domenico Silveri 3, 00165, Rome, Italy; e-mail: stefania.zezza@gmail.com, ORCID: https://orcid.org/0000-0002-1367-1538

(C) by the author, licensee Łódź University - Łódź University Press, Łódź, Poland. This article is an open access article distributed under the terms and conditions of the Creative Commons Attribution license CC-BY-NC-ND 4.0 (https://creativecommons.org/licenses/by-nc-nd/4.0/)
} 
the 20th century. The Sephardi Jews of Saloniki always remembered their bond with Spain and kept it alive through the use of Ladino, or Judeo Spanish, which was commonly spoken as their mother tongue. When Saloniki became part of Greece, in 1912, the youngest began learning Greek at school, as well as French and Italian in many cases. The fact that these languages were spoken and taught is quite telling: they represented and helped the geographical connections between the Sephardic Jews from Saloniki and other countries in the Mediterranean area.

Their command of French enabled many Salonikan Jews to move to France in the first three decades of the 20th century; the same, on a smaller scale, happened with Italy, with which the links were old and tight.

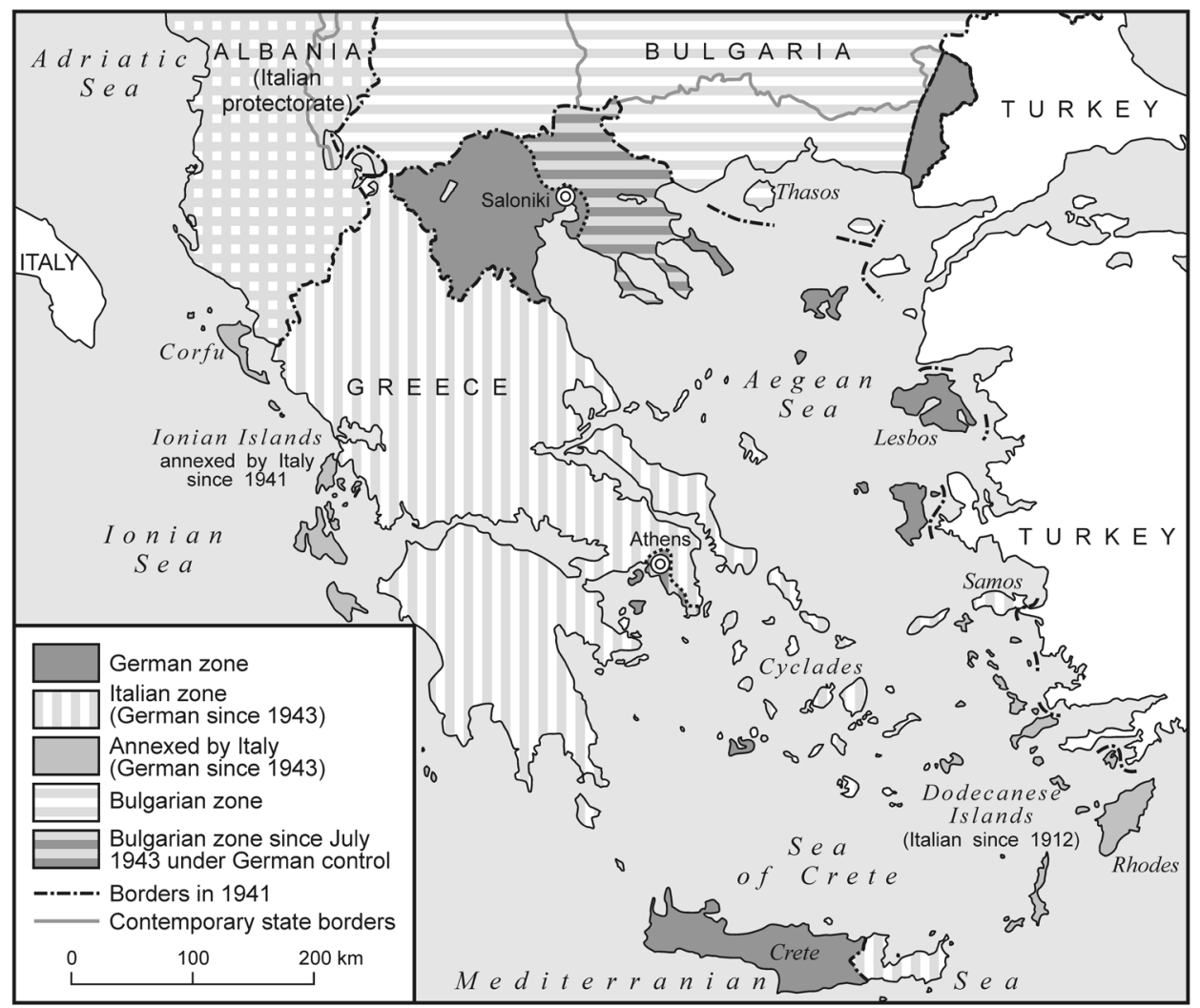

Fig. 1. Occupated areas in Greece

Source: own work based on Hillberg, 1985; Mazower, 1995; Bowman, 2009.

One of the peculiarities of the situation of Salonikan Jews during the Holocaust lied with the different treatment of resident Jews with foreign citizenships. According to German sources, there were 852 (511 Spanish, 281 Italian, 39 Turkish, 
and some Portuguese, Argentinian, etc.) such persons in Saloniki at the time of the first transport to Auschwitz, on 15 March 1943. They were exempted from the anti-Jewish measures and initially avoided deportation. Guelfo Zamboni, Italian consul in the city until June 1943, provided Jews with papers indicating their Italian citizenship, so the number of 'Italian citizens' and of those who were allowed to flee to the Italian occupation zone increased. Yet previously many problems had arisen between Germans and Italians about the implementation of the anti-Jewish measures also in the area under the Italian rule.

Italians had often refused to implement the same policy as Germans against the Jews who lived in the Italian zone or with Italian citizenship in Greece. Many documents show this attitude, which involved providing Italian papers on a relatively broad scale. In fact Guelfo Zamboni, and Giuseppe Castruccio, his successor, managed to avoid or at least delay a deportation to Auschwitz of 350 Italian Jews who arrived in Athens on 19 July 1943.

Also Spanish nationals who used to live in Saloniki were mostly protected from immediate deportation. As a consequence of a previous agreement with Franco's government, they were allowed to enter Spain temporarily: 367 of them were deported to Bergen Belsen, established originally as an exchange camp, on 2 August 1943, and were later freed and sent to Camp Fedallah in Marocco via Spain.

\section{OCCUPATION AND PERSECUTION}

Germans occupied Saloniki in April 1941 but they did not begin implementing their anti-Jewish policy until 11 July 1942, when they gathered all Jews, aged 18 to 45, in Plateia Elephteria. About 8,500 men were kept standing in direct sunlight, and forced to do calysthenics while they were being registered for forced labour. At the end of January 1943, Dieter Wisliceny and Alois Brunner were sent by Adolf Eichmann to Saloniki in order to organise a deportation from the city. The usual anti-Jewish decrees, which followed the same pattern as in other countries, were issued quite quickly: since 26 February all Jews aged over 5 were forced to wear the yellow star, and ghettos, or specific areas for Jews, were established. In particular, many Jews were transferred to the Baron Hirsch neighborhood, which was next to the railway station. When deportations began, on 15 March, the ghetto was emptied and filled again with other Jews coming from other areas of the city, like Regi Vardar.

The deportations of Salonikan Jews followed different paths; despite their limited number in comparison to that of Polish or Hungarian Jews, they eventually arrived at the main extermination and concentration camps. If one follows small groups and individual stories, studying the available testimonies and documents, 
one can understand the complexity and the extension of most of these movements. Despite its common lines, the Nazi global plan of persecution, deportation and extermination was conducted in many different ways according to places, time, and people involved. In particular, the special characteristics of Salonikan Jews played a significant role and affected their fate mostly in a negative and, rarely, in a positive way: their being Sephardi, their place of origin, i.e. a Mediterranean country, the language they spoke or they could not speak (Yiddish, for instance), their tendency to constitute, when possible, strong support groups, also due to the fact that they felt that incommunicability, which was also experienced by Primo Levi ${ }^{1}$.

The first wave of deportations from Saloniki occurred between March and August 1943 and was directed to Auschwitz Birkenau, the 19th transport ${ }^{2}$ which included 441 Jews (367 Spanish nationals and 74 members of the Jewish community administration) left on 2 August and was sent to Bergen Belsen, which at that time was the destination for Jews with the citizenship of a neutral country or for the so-called 'exchange Jews'. In July, 350 Jews with Italian citizenship had already gone to Athens, which was under the Italian rule until 8 September 1943. In fact, the last transport which included Salonikan Jews left from Athens on 2 April 1944. They had found refuge in Athens at the time of the deportations from Saloniki: the majority of them were sent to Auschwitz, where they arrived on 11 April, others, holding the citizenships of neutral states (Spain, Portugal, and Turkey), were deported to Bergen Belsen. In Vienna five cars were detached from the train directed to Auschwitz and sent north. The convoy arrived to Celle on 14 April $1944 .^{3}$

For reasons of clarity the analysis of the deportations I shall conduct separately: in the first part I shall examine the deportation to Auschwitz and from there to other camps in 1943/44, in the second part I will explain the situation of the deportees to Bergen Belsen, and in the third part the geographic directions of the evacuations and the liberation.

Many Jews of Salonikan origin were deported from France already in November 1942. They were immigrants who had moved mainly to Paris in the 1920 s and 1930s and were living mostly in the 11 Arondissement. The round up, which occurred after that of the Velodrome d'Hiver (July 1942), was called la Rafle des Grecs. They were mainly deported to Auschwitz Birkenau with the 44th transport from Drancy, only 15 of the 1000 deportees survived. Others were deported later from Paris and other cities (Karatzoglou, 2014).

\footnotetext{
${ }^{1}$ About the special characteristics of Salonikan Jews, see Primo Levi, If this is a Man; Giorgos Antoniou, A. Dirk Moses (2018) (eds.), The Holocaust in Greece, Cambridge: Cambridge University Press.

${ }^{2}$ According to Yad Vashem's deportations database. https://deportation.yadvashem.org [accessed on: 01.02.2019].

${ }^{3}$ Ibid.
} 


\section{AUSCHWITZ BIRKENAU}

Between 15 March and 11 August, about 45,000 Jews were deported from Saloniki to Auschwitz Birkenau and the majority of them were murdered almost immediately upon arrival.

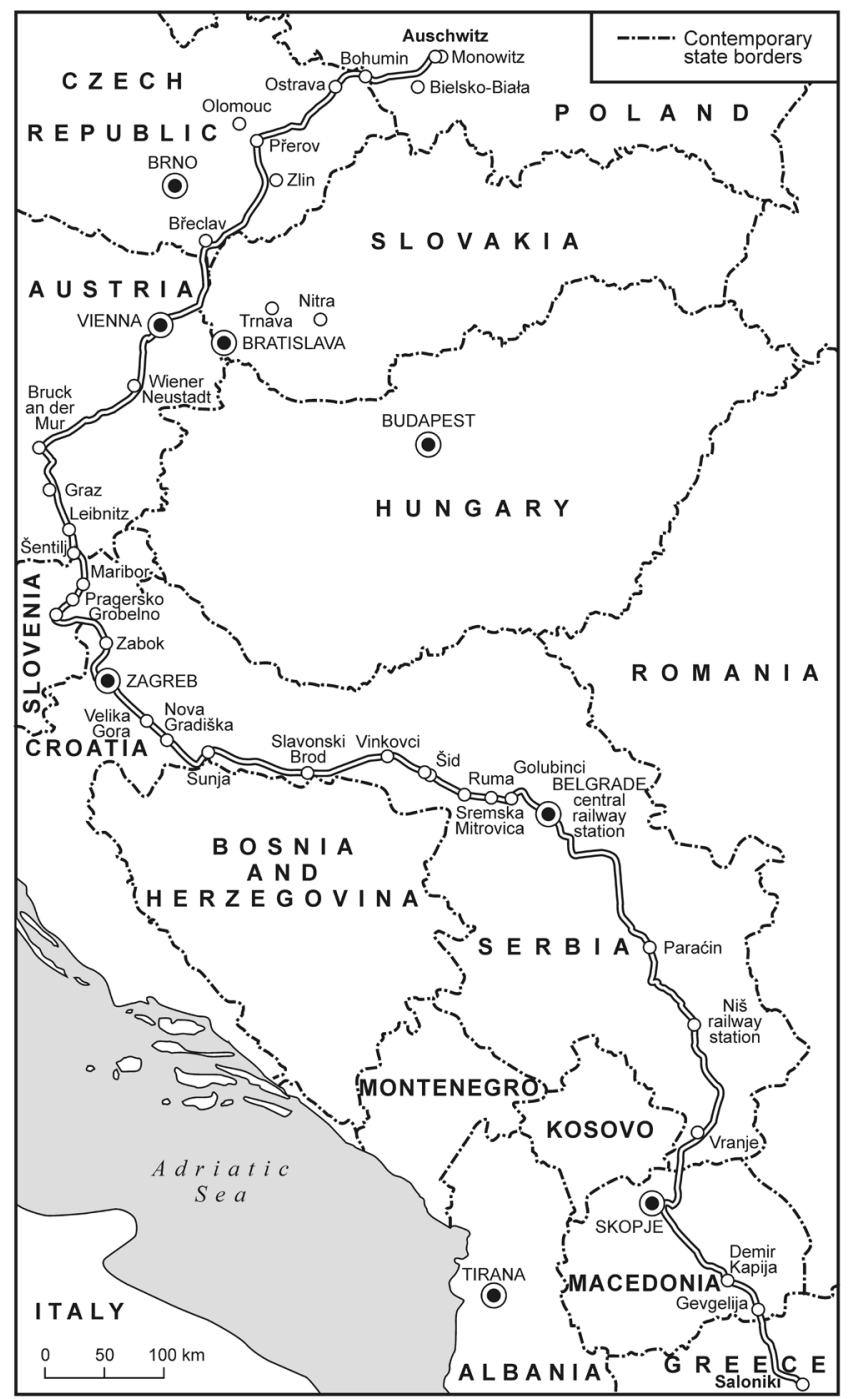

Fig. 2. From Saloniki to Auschwitz

Source: own work based on Molho, 1973; Bowman, 2009; Yad Vashem Deportation Database: https://deportation.yadvashem.org/index.html?language=en\&itemId=5603288 [accessed on: 01.02.2019]. 
A small percentage was registered and given a registration number, among them only a few managed to survive. According to Rudolph Vrba's testimony:

Early in March 1943, 45,000 Jews arrived from Saloniki. Ten thousand men and a much smaller number of women were sent to the camp. The remainder, at least 30,000 people, were sent to the crematoria. Of the 10,000 men in the camp, nearly everyone, perhaps all, died shortly afterwards. Most of them fell victims to an epidemic disease similar to malaria, many died of typhus, and others could not stand the hard conditions in the camp (Vrba and Wetzler, 1944).

The reason for this huge number of losses was also an outcome of the time of the arrival of the transports, that is the spring of 1943, when a new crematorium was put in operation, and of a high number of deportees arriving to Auschwitz Birkenau from all over Europe. Their numbers were more than enough to be exploited as forced labourers by Nazis. The Salonikan Jews who were admitted to the camp actually suffered much because of the climate, harsh living conditions, and communication difficulties as they could not speak German, Polish or Yiddish. The death toll was very high especially among women and girls. Rudolph Vrba recollected:

In view of the great mortality among the Greek Jews, resulting from malaria and typhus, selections were temporarily halted. Sick Greek Jews were told to report. We warned them not to do so, but many reported nevertheless. All were killed by intercordial injections of phenol. Such injections were administered by a medical noncommissioned officer who was assisted by two Czech doctors, Cespira Honza and Zdenedk Stich, both of Prague. These doctors are at present in the Buchenwald reception center. Both doctors did everything they could to help the unfortunates, and when they could do nothing else, eased their pain (Vrba and Wetzler, 1944).

Inside Auschwitz and Birkenau the Jews from Saloniki constituted a small group, and yet they faced all the possible experiences there: many girls and young men were used as test subjects in block 10 and 21 for sterilisation experiments (see also Photini, 2009), others worked as slave labourers in the Sonderkommando, and a few young women worked in the Union Fabrik and in the Kanada Kommando. Those who survived were mostly evacuated to camps in Germany in the late 1944 and in January 1945.

\section{IN SUBCAMPS}

Despite their limited number, many Salonikans had already been transferred from the Auschwitz Birkenau main camp to its subcamps or to other camps in Poland, Germany or Austria. Their fate and their geographical destinations depended upon their condition in the camp, at the camp where they had been transferred and were being exploited. Greeks were mainly sent to Buna Monowitz, Budy, Harmense, Fürstengrube, and Jaworzno. 


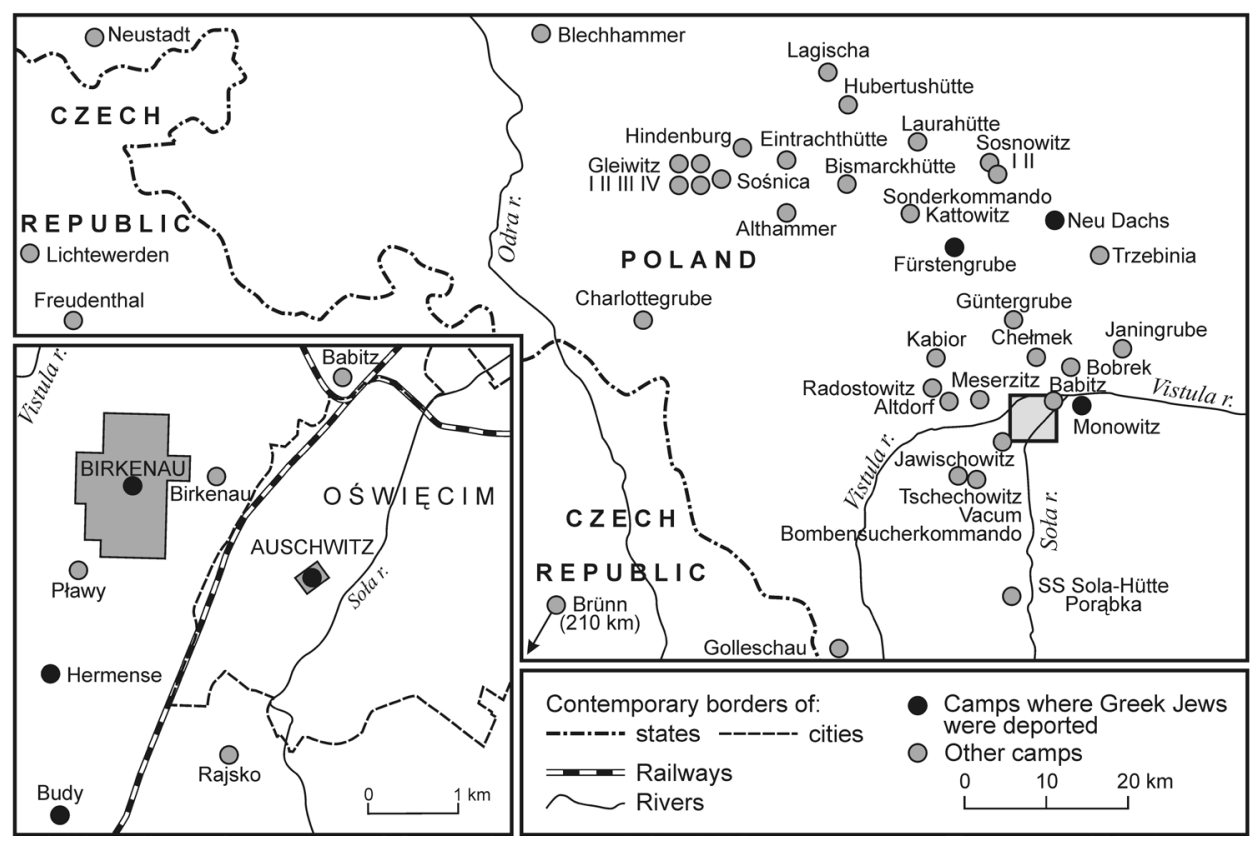

Fig. 3. The Auschwitz Complex

Source: own work based on Molho, 1973; Bowman, 2009; https:/encyclopedia.ushmm.org/ content/en/gallery/auschwitz-maps [accessed on: 01.02.2019]; http://auschwitz.org/en/history/ auschwitz-sub-camps [accessed on: 01.02.2019].

On 2 May 1943, the first group of 200 Salonikans was transferred to Buna Monowitz. This number increased later on as many others were added in the following transports. They were among the first prisoners taken there to build the factories. In Budy they were exploited for farming and the work was extremely hard.

Several men were sent to Jaworzno, at the recently established satellite camp Neu Dachs, in June 1943. The living and working conditions there were particularly harsh. A transport of 80 prisoners, mostly Salonikans, was recorded on 2 July 1943. Their number reached 1,500 in the following months. The slave labourers were forced to work in coal mines without any protection, food was inadequate, especially considering the hard work demanded of them. In his testimony, Henry Bulawko, one of the prisoners, talked about three Greek Jews who chased a dog and stole some bones from it (Langbein, 2004, p. 112).

Despite their difficulties with communication and their limited number, Greek Jews were visible and active inside the camp. Martin Shlanger, a former prisoner, talked about them in an interview for the Voice Vision Holocaust Survivors Oral History Archive on 4 March 1983. When discussing the sanitary conditions inside Neu Dachs, he stated: 
There was no running water. There were wells but the water was terrible (...) Because the area was full of coal mines, probably for that reason. I think it was full of sulfur. That's what I think. Many people were getting uh, dysentery from it but we were drinking it. At night we had um, big drums at the door and during the daytime there were latrines, not inside the barracks, we had to walk out. But at night, we were not allowed to walk out. On the construction project there was a Scheissmeister and prisoners were not allowed to be in the, on the, in the latrine for more than uh, five minutes. After five minutes, the Scheissmeister came with a stick and chased the prisoner out of the latrine...the Scheissmeister on the construction project was a Greek. And he tried to help the prisoners as much as he could. A Greek prisoner...Greek Jew. ${ }^{4}$

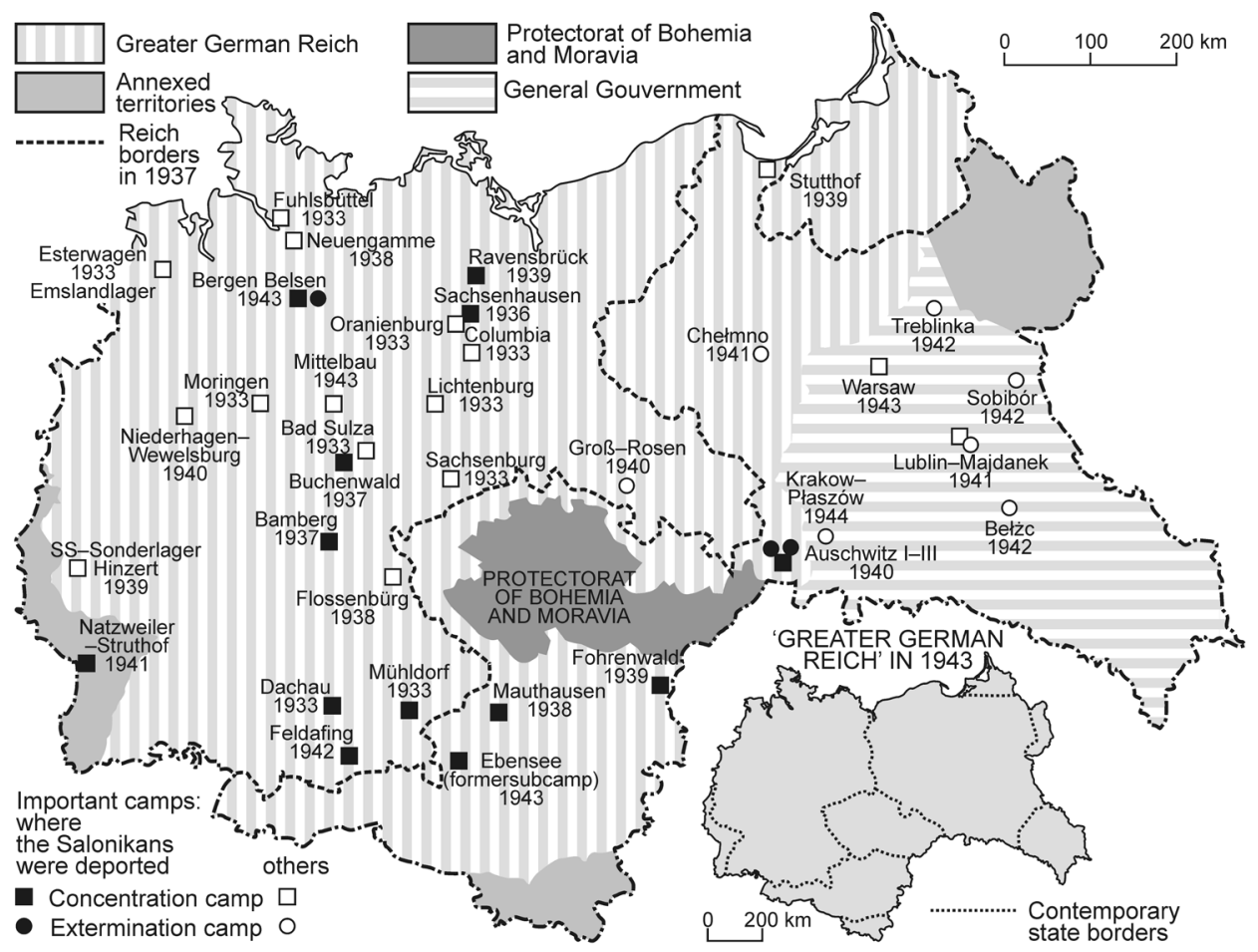

Fig. 4. Camps to which Salonikan Jews were deported

Source: own work based on Molho, 1972; Novitch, 1977; Pinhas, 2006; Bowman, 2009; https://encyclopedia.ushmm.org [accessed on: 01.03.2019]; https://voices.iit.edu/

[accessed on: 09.03.2019].

Michael Molho wrote that Jaworzno was the cemetery of Greek Jews: they died from starvation, exhaustion, and many were shot by the SS. At the end of October 1943 about 1,000 were sent to the crematoria, fifteen days later another group of 250 shared the same fate. The few who survived, 12 according to Molho, were evacuated from Jaworzno to Gross Rosen and then to Buchenwald on 17 January 1945 (Molho, 1972).

${ }^{4}$ http://holocaust.umd.umich.edu/shlanger/ [accessed on: 10.01.2019]. 
At the end of July 1943, many Salonikan Jews were sent to Fürstengrube, another subcamp active from September 1943 to 19 January 1945, where the prisoners were forced to work in coal mines. Benjamin Jacobs recalled in his memoir, The Dentist of Auschwitz: "By the end of July Greek Jews from Saloniki were delivered to Fürstengrube. None of them understood German, but they proved themselves to be tougher than any of us" (Jacobs, 1995, p. 189).

Hermann Langbein in his People in Auschwitz wrote that Dr. Miklos Udvardi stated: “(...) in late July or August 1944 five or six inmates were publicly hanged in Fürstengrube. (...) those hanged were Poles and Jews from Greece and Italy." (Langbein, 2004, p. 279).

\section{FROM AUSCHWITZ TO MAJDANEK}

On 27 May 1943, an order was issued to transfer about 800 prisoners suffering from malaria, aged 16 to 20 years, from Auschwitz to Lublin Majdanek. They left on 3 June and arrived there two days later. "At the beginning of June, over 800 Greek Jews, men and women, arrived at the camp from KL Auschwitz ..." (Kranz, 2007, p. 25).

They were to become the test subjects for a new malaria medicine in the experiments conducted by SS doctor Heinrich Rindfleisch (Weindling, 2014). According to Vrba's testimony:

Four hundred Greeks suffering from malaria were sent to Lublin for "further treatment", following the suppression of the phenol injections. We received news of their arrival in Lublin, but we know nothing about their fate (Vrba and Wetzler, 1944).

Many Greek women were actually suffering from typhus, not just malaria, nevertheless they were given a new medicine which did not treat them at all. These women, placed in a separate barrack, all died by September 1943. ${ }^{5}$ Testimonies, among them Dr. Alina Brewda's account, confirm the fact that all the women died there. ${ }^{6}$ Brewda

\footnotetext{
5 "The transport of Greek Jews from KL Auschwitz, who according to notes were suffering from malaria, arrived at Majdanek on 5 June 1943. It contained 542 men and 302 women aged 16 through to 20. Most likely these prisoners were transferred for the purpose of testing a new malaria medicine. The infectious disease treatment tests were carried out by SS Doctor, Heinrich Rindfleisch, who placed the Greek women in a separate barrack and ordered them to be administered an unknown preparation. In fact, many of them suffered from typhoid fever, which decimated their group in a short period of time. Cf. I Shall Fear No Evil. The story of Dr. Alina Brewda. ed Robert J. Minney (London), pp. 91-92" (Kranz, 2007, p. 25).

6 "The Majdanek camp doctor Heinrich Rindfleisch conducted unofficial experiments on treatment of infectious diseases. He carried out therapeutic experiments on 300 female Jews (originally from
} 
was captured in the Warsaw ghetto on 22 April 1943, during the Warsaw Ghetto Uprising, and she was sent to Majdanek.

"I got to the Majdanek camp, where I stayed until September 22, 1943. At that time, I ran a block of malaria patients - Greek - and I was a gynecologist surgeon at the entire Majdanek district."

On 23 July 1943 a report about the countries of origin of male prisoners was made: out of the 4,710 Jewish prisoners inside the camp 449 came from Greece. ${ }^{8}$ The Communique of the Polish-Soviet extraordinary Commission for investigating the crimes committed by the Germans in the Majdanek extermination camp in Lublin, includes another testimony about the presence of Greeks. Tadeusz Budzyn, M. Sc. Chem., a Pole, and formerly a prisoner at the camp, stated:

The Germans compelled a large group of professors, physicians, engineers and other specialists, numbering one thousand two hundred in all, who came from Greece, to carry heavy stones from one place to another, a task which was far beyond their strength. The scientists who dropped from exhaustion as a result of this heavy labour were beaten to death by the SS men. Owing to the system of starvation, exhausting labour, beating and murder, the entire group of Greek scientists was exterminated in the course of five weeks. ${ }^{9}$

Some Greeks were still in the camp in 1944, as a witness, Alina Paradowska, testified on 30 September 1947: "In 1944, I saw Muhsfeldt ${ }^{10}$ on the road playing an active role in the selection of Jewish Greeks brought to the camp and destined for execution." 11

\section{FROM AUSCHWITZ TO NATZWEILER}

On 30 July 1943, 86 Auschwitz prisoners, 60 men and 26 women, were sent to Natzweiler-Struthof, where they were killed in gas chambers. They had been selected by two anthropologists, Bruno Beger and Hans Fleischhacker. According

Saloniki), aged sixteen to twenty, transferred from Auschwitz to Majdanek, because they had malaria, in May 1943. They died by September." Weindling, 2014, p. 236.

${ }^{7} \mathrm{https}$ ://www.zapisyterroru.pl//Content/4070/Brewda_Alina_2_pl. [accessed on: 01.04.2021].

${ }^{8}$ APMM, KL Lublin, I c 2, v. 1.

${ }^{9}$ Communique of the Polish-Soviet extraordinary Commission for investigating the crimes committed by the Germans in the Majdanek extermination camp in Lublin (1944), Moscow: Foreign Languages Publishing House.

${ }^{10}$ Erich Muhsfeldt (1913-1948). He was in charge of the gas chambers in Majdanek until May 1944.

${ }^{11} \mathrm{https}: / /$ www.zapisyterroru.pl//Content/3614/Paradowska_Alina_en.html?hl=majdanek [accessed on: 01.04.2019]. ALINA PARADOWSKA. On 30 September 1947 in Łódź, Investigating Judge of the Third Region of the District Court in Łódź, S. Krzyżanowska, with the participation of court reporter Maria Adamczyk, heard the person named below as a witness. Having been advised of the criminal liability for making false declarations and of the wording of Article 107 of the Code of Criminal Procedure. 
to Paul Weidling, Beger aimed to demonstrate that the Jewish race was racially complex. He was fascinated by the wide range of Jewish types in Auschwitz and was particularly interested in Greek Sephardic Jews, whose presence was massive in Block 10.

Between 11 and 19 August 1943, 46 Salonikan men and women, among the prisoners previously selected, were murdered in a small gas chamber in Natzweiler-Struthof and their corpses were sent to the Anatomy Laboratory of the Strasbourg University Medical School in order to be collected for a Jewish skeleton collection. The laboratory was headed by Dr. Hirt, who was not a doctor, but taught at the university. He had asked Himmler for a permission to get some well preserved bodies for his work. That was the reason why 86 Auschwitz prisoners, whose biometric measures had been previously taken, were sent to Natzweiler-Struthof and murdered: their heads were removed, and their bodies were cut into pieces and preserved. This story was not completely known until a German researcher, Dr. Joachim Lang, investigated and identified the victims (Lang, 2004). Their names were recorded by Henry Pierre, Dr. Hirt's assistant and his notes helped in the identification process. An official ceremony occurred in December 2005, and eventually a memorial plaque with the names of the victims was placed on the site where their remains had been buried. ${ }^{12}$

Another transport which took several Salonikans from Auschwitz to Natzweiler-Struthof occurred on 28 October 1944; some, like Juda and Moise Akunis, were deported from Saloniki with the first transport to Auschwitz. ${ }^{13}$

\section{FROM AUSCHWITZ TO WARSAW}

A group of prisoners, among them many Salonikans and Greek Jews from the north, was transported from Auschwitz Birkenau to Warsaw (see also Zezza, 2020 , p. 4) ${ }^{14}$ in late August (501 according to Molho (Molho, 1973), among them 233 from the last transport from Saloniki), in October (200 according to Molho), and in November (850 according to Molho) 1943: all the testimonies confirmed the fact that the prisoners were chosen since they could not speak Polish. They were sent to KL Warsaw Gęsiówka, which Himmler had established inside the area of the former ghetto, in order to remove the debris after the end of the Ghetto

\footnotetext{
${ }^{12}$ From Auschwitz to Natzweiler (Professor Pierre Biermann of Luxemburg testified at the Nuremberg Trial [NO-814] to experiments in Natzweiler (January-September 1943) and Buchenwald (September 1943-April 1945)).

${ }^{13}$ ITS Bad Arolsen Archives Incarceration Documents / 1.1 Camps and Ghettos / 1.1.41 Stutthof Concentration Camp / Personal Files - Stutthof Concentration Camp Reference Code 01014102 oS.

${ }^{14} \mathrm{https}$ //www.sephardichorizons.org/Volume10/Issue3\&4/Zezza.html.
} 
revolt and to collect all the building material which was to be sent to Germany. In fact, in July 1943 Himmler made the decision to erase any traces left of the former ghetto and of the Jewish presence in Warsaw, and to create a park in the area. "The transport was composed only for Greek people. The reason - because we don't speak Polish and the job was in contact with the Polish civilians and they don't want the Polish Jews." 15

Vrba remembered: "Approximately 1000 survivors of the 10,000 Greek Jews were sent with another 500 Jews to build fortifications in Warsaw. A few hundred of these returned several weeks later in a hopeless condition and were immediately gassed." ${ }^{\prime 16}$ The harsh conditions inside the camp were also recalled by Moshe Salmon:

We arrived in Poland, in Warsaw, we were transferred by train. ... there was another camp, some barracks. Just real, real primitive. No organized camp, no nothing. Just barracks. Everybody got a billet bag, for pillow, for blanket, for everything. ... The disease started to spread in camp. My brother-in-law and I, we fell with the typhoid. .... I don't remember how long we stayed in the hospital. People they used to die by drinking water, not clear water. ${ }^{17}$

Germans thought that the inability to communicate could prevent the prisoners from escaping. Yet the Salonikans managed to have contacts and to trade with the Poles.

Every day a hundred or so Poles would enter the ghetto to work at clearing away the ruins, and they all did business with the slaves of the Warsaw camp. They brought in food and carried off riches. The biggest "merchants" were the Greek Jews, most of whom came from Saloniki. They were specially talented at "organizing", what they called 'klepsi-klepsi' - that is articles from "nonkosher" sources such as thievery (Charmaz, 2003, p. 112).

In the Gęsiówka camp the Salonikans not only could see the destruction of the Warsaw ghetto but they also experienced the first 'death march' (Krakowski, 1989 ) at the end of July 1944: while the Red Army was approaching Warsaw, a major group of the prisoners was evacuated to Dachau and its subcamps. According to Steven Bowman (2014) only 280 Greek prisoners arrived at their destination alive. For the Greeks there was neither an opportunity nor a possibility to escape, as Yehiel Daniel recalled:

Where would you escape to? Do you know where to escape to? What escape? Who thought about escaping? You don't know - Poland, not Poland, not Germany. Maybe you are between Poland and Germany. ... You don't know the language, you don't know a thing. Also, it's better to be together. ... Exactly where I would go? (Blatman, 2014, p. 66).

\footnotetext{
${ }^{15}$ MOSHE, S., Oral History Transcript. http://wisconsinhistory.org/HolocaustSurvivors/Moshe.asp [accessed on: 05.05.2019].

${ }^{16}$ VRBA, R., op. cit.

${ }^{17}$ MOSHE, S., Oral History Transcript. http://wisconsinhistory.org/HolocaustSurvivors/Moshe.asp [accessed on: 05.05.2019].
} 
The prisoners had to walk to Kutno where they were evacuated to Dachau. "Now, the march from Warsaw, the worst part, was this, was in August - hot. It was July, August, I don't remember exactly, but it was really warm. They wouldn't give you water, no water." 18

David Lea, one of the Salonikan survivors interviewed by David Boder ${ }^{19}$ in 1946, remembered the terrible trip:

On a transportation that came from Warsaw, in 1944, when the Russians were approaching Warsaw. The biggest transportation, and the biggest disaster in Jewish history was in Warsaw where they deported us on train for 18 days. On animal trains, locked day and night, guarded by four barbarians of the SS, with their machine guns, no water, no food, and under the sun ... And more than 8,000 people died. We were 8,726 people and 725 people returned to the Dachau camp. The 8,000 people were killed by starvation, or by the SS, or by the drought. ${ }^{20}$

Lea and the other prisoners from Warsaw were registered in Dachau on 6 August $1944^{21}$ and were exploited as slave labourers in subcamps until their liberation.

Many were sent to Mühldorf, others to Landsberg Kaufering, and some to Karlsfeld. A few were deported to the Flossenburg subcamp Leitmeritz in January 1945. For instance, Lea remained in Kaufering until its liberation. Eleiezer and Isaac Sotto were transferred to Leitmeritz on 7 January 1945.

We stayed until 1944 in Warsaw. In 1944, they evacuate the camp because the Allies was pretty close, and they took us to Dachau. We march a whole week, and they put us in the train to go to Dachau. We arrive in Dachau, and we stay for a couple of weeks, and then we transfer to another camp: Number 4. They have different camps, Number 1, Number 4, Number 7. Then from Number 4, I went to Lager [German: camp] 7. I think that was in Landsberg, Germany. Then from Landsberg, Germany, we got transferred to Leitmeritz. That was in Czechoslovakia. We were working in a town over there. ${ }^{22}$

483 prisoners were left in Gęsiówka, 41 of them were Greeks and only 14 of them survived. They were freed by Polish partisans on 5 August 1944, and made the decision to fight with them against Germans during the Warsaw Uprising. When the revolt failed and Germans regained control of the city, the survivors hid in bunkers or in the woods near Warsaw. They were liberated later by the Red Army.

\footnotetext{
${ }^{18}$ MOSHE, S., op. cit.

${ }^{19}$ On 4, 5, and 12 August 1946, David Boder interviewed in Paris seven Holocaust survivors from Saloniki. These interviews represent some of the few documents which provide direct information on the fate of Salonikan Jews and reveal much more than other testimonies in terms of historical details, perception of the events, and background information.

${ }^{20}$ Interview with David Lea. http://www.voices.itt.edu (now https://voices.library.iit.edu/) [accessed on: 09.02.2019].

${ }^{21}$ Copy of 1.1.6.1 /9956424 in conformity with the ITS Archives, Bad Arolsen. Namentliche Aufstellung über Häftlinge, die im Konzentrationlager Dachau inhaftiert waren.

${ }^{22}$ Interview with Eliezer Sotto. The William Breman Jewish Heritage Museum Esther and Herbert Taylor Jewish Oral History Project of Atlanta Legacy Project. https:/www.thebreman.org/Research/ Southern-Jewish-Archives/Oral-Histories [accessed on: 10.04.2019].
} 


\section{SALONIKAN JEWS IN BERGEN BELSEN}

Salonikans were deported also to Bergen Belsen: those with Spanish citizenship got there in August 1943 together with members of the Jewish Council.

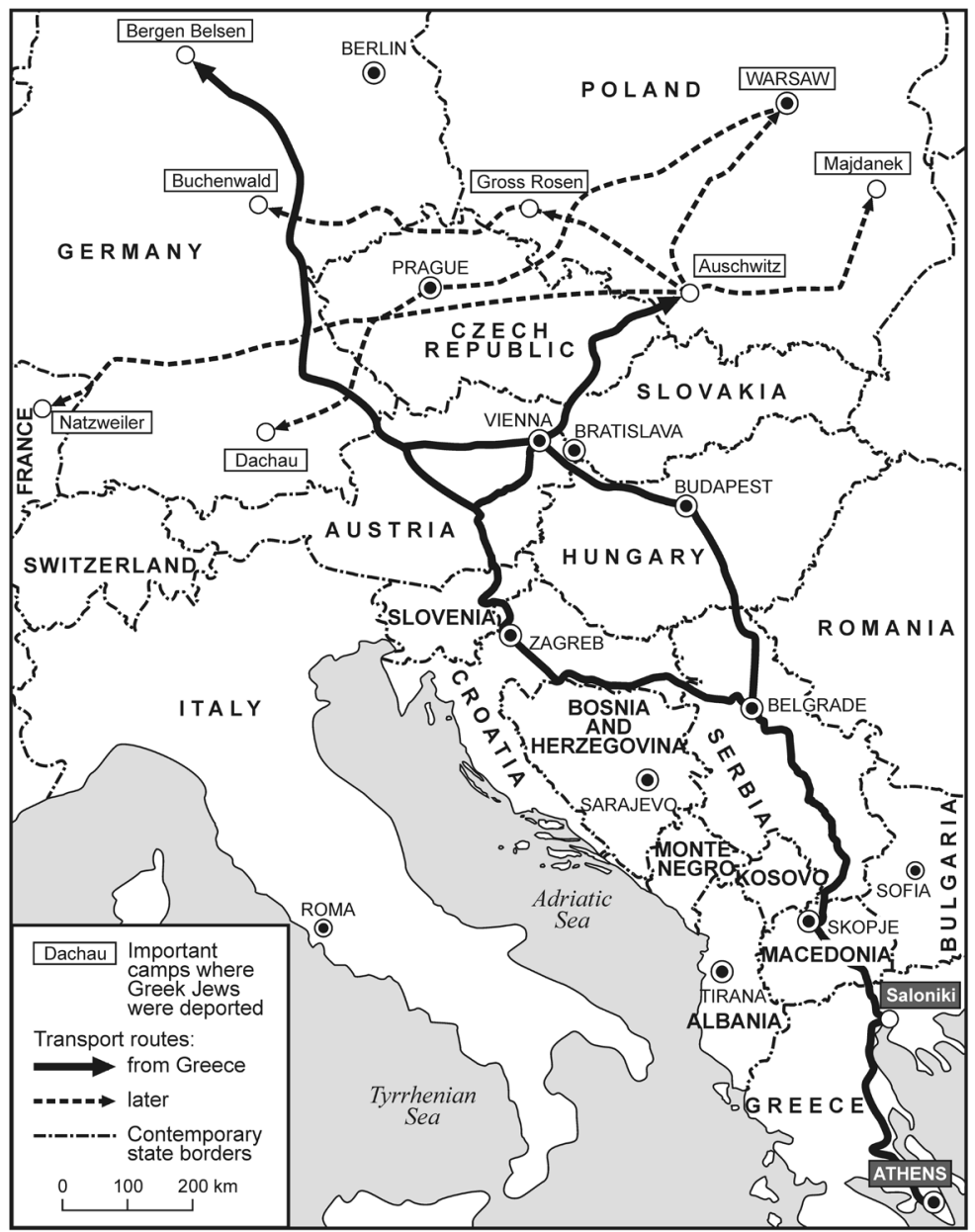

Fig. 5. From Greece to Bergen Belsen (April 1944)

Source: own work based on Molho, 1973; Novitch, 1977; Bowman, 2009; http://buchenwald.de [accessed on: 06.02.2019]; http://voices.itt.edu (now https://voices.library.iit.edu/) [accessed on: 09.02.2019]; https://collections.arolsen-archives.org [accessed on: 02.03.2019]; https://deportation. yadvashem.org. [accessed on: 01.02.2019].

On August 2nd a certain number of so called 'privileged' were deported to Bergen Belsen, to these people were added the leaders (of the Jewish Council), some functionaires and artisans 
who had been kept (in Saloniki) by the Germans for their purposes. With this same convoy and to the same destination 367 Jews with Spanish citizenship were deported. Spain had refused to let them enter... (Molho, 1973, p. 110).

These Spanish nationals left the camp in February 1944, passed through Spain and arrived in the Fadhala Camp in Morocco, from where they eventually went to Palestine. As Dieter Wisliceny stated in his affidavit:

... about 700 Jews of Spanish nationality were transported in August 1943 to Bergen-Belsen and in December to Spain. These Jews had obtained their Spanish nationality during the last century while Greece was still under Turkish rule. ${ }^{23}$

\section{Jack Revah recollected:}

Our group eventually left for Spain. The first convoy left on February 4, 1944, the second on 7. We travelled in third class wagons. A representative of the Joint, Dr. Sequerra, was waiting for us at the Spanish border. On February 14 we arrived to Barcelona. On June 15 we were sent to Madrid, on 21 we arrived to Casablanca; we were housed in a camp close to the city of Fedallah. This camp was directed by Mr. Backelman, we were treated well and stayed there until November 13, 1944. Passing through Port Said, where we arrived on November 27, we went to Palestine, where half of us made the decision to stay (Novitch, 1977, p. 32).

The second group was sent to Bergen Belsen from Athens in April 1944. Jacob Button, interviewed by David Boder, gave a detailed account of the trip: the train travelled through Serbia, Hungary, Austria, and Germany. $\mathrm{He}$ remembered that the train stopped at the central station in Budapest, where the deportees could see the stars worn by Hungarian Jews: to wear the star had become compulsory on 5 April 1944. He also remembered that the train was divided into two different convoys in Vienna: one went to Auschwitz, the other to Bergen Belsen.

Like other witnesses, Button said that the deportees had to walk from the station, in Celle, to the camp. They were considered exchange Jews and were kept in the camp in harsh living conditions, suffered from starvation, diseases like typhus, but they did not have to work and were not subjected to selections and extermination by gas. They remained in the camp until April 1945.

Others arrived there, as in many other camps and subcamps in Germany, after the evacuation of Auschwitz, when Bergen Belsen had lost its original function and had become the destination for thousands of prisoners after the death marches. People were left dying without housing facilities, food or water, since the camp, which had been originally planned to host a few thousand inmates, hosted about 60,000 at that time.

${ }^{23}$ Affidavit of Dieter Wisliceny. Source: Nazi Conspiracy and Aggression. Volume VIII. USGPO, Washington, 1946, pp. 606-619. (This affidavit is substantially the same as the testimony given by Wisliceny on direct examination before the International Military Tribunal at Nurnberg, 3 January 1946). 


\section{EVACUATIONS}

As the Red Army was nearing the Auschwitz complex, about 60,000 prisoners were forced to leave the camp and march to western camps inside Germany to be exploited as forced labourers in the armament industry. The death marches, as they are commonly known, began on 17/18 January and were so chaotic and disorganised that the prisoners often reached their final destinations after several weeks. Most of them were later transported to other subcamps, sometimes switched between two or three, where they were eventually liberated. Those Salonikan Jews who had managed to survive in the Auschwitz complex were among these prisoners. For some days after 18 January they marched out from Auschwitz and its subcamps. They were forced to walk in the snow for many kilometers before reaching a railway station from where they were transferred to camps in the west. Moshe Haelion ${ }^{24}$, aged 20 at that time, from Saloniki, remembered leaving with thousands of other prisoners on foot on 21 January, and four days later he arrived in Mauthausen. The living conditions inside the camp were extremely harsh and he volounteered to go to work in Melk where the situation was not better, though: when he arrived there, the camp had reached its maximum capacity: on 30 January 1945, there were 10,352 prisoners. The last group of prisoners was transported there on 29 January 1945. They worked inside caverns without any protection.

As the Allied Forces were approaching, the prisoners were evacuated in April mostly to Ebensee. They went to Linz by boat and, after two days, passing through Wels and Lambach on foot, they arrived at the camp. There they worked at the railway station until their liberation, on 6 May 1945. There were about 180 Greek Jews who survived there, among them Dario Gabbai, who had taken part in the Sonderkommando revolt in Birkenau, and Jacques Stroumsa.

Another group of prisoners, among them Henry Sochamy, one of David Boder's interviewees, were taken to Breslau Lissa and then to Buchenwald.

A month before the Russians' arrival, the camp was evacuated and we were sent to a camp in [unintelligible name]. ${ }^{25}$ In [unintelligible name], there were only forty Jews, and the rest of the prisoners were Christian. ${ }^{26}$

Breslau Lissa was the first subcamp of Gross Rosen. It was established in 1942 and in 1944 it hosted the FAMO plant. Henry Sochami said that in February 1945

\footnotetext{
${ }^{24}$ Oral history interview with Moshe Haelion. USHMM. Oral History | Accession Number: 2014.428.9 | RG Number: RG-50.822.0009.

${ }^{25}$ The interviewee says Breslau Lissa, but David Boder couldn't understand the name of the camp and transcribed it as Breslaolita.

${ }^{26}$ Interview with Henry Sochami/Suchami. www.voices.itt.edu (now: https://voices.library.iit.edu/) [accessed on: 09.02.2019].
} 
he was evacuated to Buchenwald. ${ }^{27}$ Most probably, Sochami was one of the 7,800 Jewish prisoners who were sent from Gross Rosen to Buchenwald between 10 February and 5 March 1945. Hundreds of them died in open freight cars, while those who reached Buchenwald alive were exhausted, starving, and seriously ill. ${ }^{28}$

He was housed in a block together with prisoners deported from many countries; those who were fit for work were sent to camps throughout Germany. He managed to hide, but eventually was sent to what he called campo chico, and quartered in an overcrowded barrack. It was the Kleine Lager, the Little camp, inside Buchenwald, which was a quarantine area and a transit camp, built in the northern zone of the Lager in 1942. Prisoners were sent from there on to subcamps after some weeks. At the time when Sochami arrived there, it was overcrowded due to mass transports from camps in the East.

When the American forces were approaching the camp, on 6 April, the camp commandant issued an order to evacuate. From the following day, about 28,000 prisoners were evacuated, the guards gathered all Jews and later killed them on the road. The interviewee, whose Jewish identity was not known by the other inmates because Jews were not recognisable there as they were in Auschwitz, managed to hide in an underground bunker with some Russians and emerged from it on 11 April, when the American forces liberated the camp.

Other Salonikans who had been evacuated from Auschwitz and taken to Buchenwald were evacuated and sent to Theresiendstadt, where they were later liberated.

In particular it is interesting to follow the fortunes of a group of young women who arrived in Ravensbrück, whose experience is quite paradigmatic (see also: Zezza, 2018). Ravensbrück was the first camp for women established by the Nazis in 1939 and it operated until May 1945. The camp's history is complex and had to be divided into different phases, quite different from one another. Once a camp for political prisoners, it became, in its final phase, a transit camp as well as an extermination camp, provided with gas chambers. At that time, Jewish women, who had been absent from the camp for four years, after the Reich had been declared Judenfrei, returned and their numbers was impressive. In January 1945 Ravensbrück appeared much different from what it had used to be at the beginning and in its following phases: the number of arrivals drastically increased in 1944 and 1945, when approximately 100,000 prisoners were deported there from other camps or occupied countries. This number was almost ten times bigger than that of the deportees who arrived at the camp in the previous four years.

It is in this final phase, i.e. from late autumn of 1944 to April 1945, that most of the Greek women arrived at Ravensbrück. Eleven of them were registered in the list of the transport no. 42 from Auschwitz Birkenau. Some others, whose names

\footnotetext{
${ }^{27}$ Once again the transcription of the interview shows a misunderstanding: the word 'Buchenwald', recognisable in the audio recording, was interpreted as 'empujando'.

${ }^{28} \mathrm{http}: / /$ buchenwald.de/en/463/\#.dpuf [accessed on: 06.02.2019].
} 
are not in the few lists which were not destroyed, gave testimony about their deportation and imprisonment in the camp after the war.

Unlike the majority of Ravensbrück prisoners coming from other countries, Greek women were not deported to the camp directly from their country of origin. They were taken there after spending about 20 months in Auschwitz Birkenau, and for many of them Ravensbrück was only an intermediate step to subcamps like Rechlin/Retzow, Malchow or Neustadt Glewe. In fact, Ravensbrück was the centre of a system of 40 subcamps, which were established for female prisoners in different towns in Germany. Those closer to the main camp, about 20, stayed under Ravensbrück's jurisdiction until the liberation, while the other were assigned to geographically closer camps in the summer of 1944. During the last weeks of April, almost all the documents and papers regarding the camp were destroyed, yet some survived. One of these is the transport list no. 42 from Auschwitz-Birkenau to Ravensbrück ${ }^{29}$ which includes 11 names of Greek young women (aged 17-22) who were deported to Auschwitz from Saloniki between March and April 1943 and arrived at the camp on 23 January 1945.

Most of the Salonikan girls who were later evacuated to Ravensbrück had been deported from Saloniki in the spring of 1943 and shared the same duties: some of them, like Rita Benmayor, worked outside for some weeks or months digging or working in the ponds. Those who survived the first months were later transferred to work at the Kanada Kommando in Birkenau, among these some ended up working at the Union Fabrik, from where they left on 18 January.

Another group of survivors, who were evacuated to Ravensbrück, were among those who had been selected to be used as test subjects in Block 10 in Auschwitz. From the testimonies given by some of these women it is possible to reconstruct their path. They left the Auschwitz complex on 18 January and they walked to Breslau, then were put onto open wagons and passed through Frankfurt am Oder and Berlin before arriving at their destination. From there, after some weeks, they were sent to the satellite camps. From 1944 on, the use of female labour in the Ravensbrück camp complex was increasing. At least fifty per cent of the new arrivals were sent to work elsewhere: Ravensbrück became a transit point for exploitation of forced labour in subcamps. Some of the Greek girls, like Palomba Allalouf, were transferred to Malchow by bus:

One morning after eight days they told us Zählapell, Zählapell... We all were outside and a German came: you out, you out. Frieda and I were among the ones he called out. They put us in a bus... (Lewkowicz, 2009) ${ }^{30}$

\footnotetext{
${ }^{29}$ Überstellung Nr. 42 aus Auschwitz, APMO, MF nr 55, k. 2401-2419.

${ }^{30}$ See also Testimony of Palomba Alaluf, born in Saloniki, Greece, 1926, regarding her experiences in Saloniki, Auschwitz and Ravensbrück. Record Group 0.33 - Testimonies, Diaries and Memoirs Collection File Number 6564 Tape Number 0.33.C/5048. Language: Greek. Date of creation - 17/02/1989. https://testimonies.yadvashem.org/index.html?search=\&language=en [accessed on: 20.06.2017].
} 
Others, like Lisa Pinhas and Rita Benmayor ${ }^{31}$, were transferred to Rechlin/ Retzow, an airfield close to the Lärz airport. Lisa Pinhas remembered that it was February and they used to work in the woods or in the airfield, digging and cutting tree branches to hide planes. The living conditions were extremely harsh due to overcrowding, the reduction of rations, and an epidemic caused by insufficient hygiene.

A devastating air raid destroyed the airfield on 10 April and the prisoners were forced to clear the ruins. A few days later some prisoners were taken back to Ravensbrück where Greeks stayed in the same block as the French.

After some weeks spent in Ravensbrück, Frieda Medina Kovo ${ }^{32}$ was transported to Neustadt Glewe, Meklenburg, where women worked in the woods and in Dornier Works at the military airfield in the proximity of Neustadt-Glewe, district of Ludwigslust.

Kovo was assigned to camouflage airplanes. She remembered that on 23 April 1945 the airport was heavily bombed, and the girls hid in the woods which were burning as the airfield did. On 2 May, the guards locked the prisoners inside the barracks and left. In the afternoon Russian forces entered the camp.

On 27 April, the evacuation of Ravensbrück had begun. Pinhas remembered they marched to Malchow, which they reached on the night of 28 April.

Benmayor was sent to Malchow, directly from Retzow. There she stayed until Germans left the camp when, together with some other prisoners, she went to a village looking for food. When Russian forces arrived, they went back to the camp.

\section{LIBERATION AND DISPLACED PERSONS (DP) CAMPS}

The camps in the west were liberated on different days during the spring of 1945. For the survivors the liberation was the beginning of a new phase: on the one hand, they had to cope with their traumas and losses, but on the other, most of them lived in a sort of a limbo since they did not want to go back to their countries of origin nor could they immediately find a place to go to to begin a new life. In the meanwhile, most were temporarily housed in the Displaced Persons camps set up by the liberators. From there, some returned to their homelands after a while, others chose a new path which took them to different places and eventually to their new countries.

\footnotetext{
${ }^{31}$ Interview with Rita Benmayor. www.voices.itt.edu. The documents about Rita Benmayor were provided by the ITS Bad Arolsen: Copy of 6.3.3.2 / 98820205, Copy of 6.3.3.2 / 98820211, Copy of 6.3.3.2 / 98820213, Copy of 6.3.3.2 / 98820214 in conformity with the ITS Archives, Bad Arolsen. ${ }^{32}$ https://collections.ushmm.org. Oral History | Accession Number: 1995.A.1272.76 | RG Number: RG-50.120.0076 [accessed on: 09.02.2019].
} 
According to the analysed testimonies and the documents, it is possible to identify some of the paths the survivors followed after the liberation. This topic, however, needs to be studied in more detail since there are many documents available in the JDC archives, in Bad Arolsen ITS and in other archives, as well as in the testimonies which can provide further information on it.

The first group of Salonikans with Spanish citizenship, deported to Bergen Belsen in August 1943, could leave the camp on 7 February 1944. From there they were sent to Spain, where Franco had accepted to let them stay only temporarily. They spent four months in Barcelona, until 14 June 1944, when they left for Casablanca and resided in Camp Fadallah. Eventually this group was sent to Palestine: after 9 August 1945, many of them returned to Greece, and 150 made the decision to remain in Tel Aviv (Molho, 1977).

The other group of Salonikans, who arrived in Bergen Belsen in April 1944, was evacuated in April 1945 while being sent to Theresiendstadt as a result of Himmler's attempt to find an agreement with the Allies. The train, loaded with prisoners of Spanish, Turkish and Portuguese citizenship, left Bergen Belsen on 10 April. It was bombed and damaged while travelling, the Americans accidentally run into it on 13 April. Nino Barzilai, one of David Boder's interviewees, gave a very detailed account of this event:

... we were placed on a train and we were told we were to be taken to Spain, but we came to Börgermoor (Magdeburg). There, there were a number of bombings by Americans, that lasted for a whole night. In the morning, when we woke up, we noticed the Germans had left the train and we had been left on our own in the camp ... completely abandoned. A number of us marched to some nearby German houses to see what was going on. We were looking for some food, because we did not cook, and we had eaten all the food we had been given for the journey. We found some potatoes and we came back to the train where we boiled them to eat something. Meanwhile, there was a rumor that the Americans had arrived. And some time later, we happily received the Americans who had come to [unintelligible]. Their first concern was to give us something hot to eat, and we were served a soup right there on the train. After a day, we were told we were going to be transported to another place. We were told to gather in the park of the town to march together to some houses they had prepared for us to stay in. ${ }^{33}$

Some of them, since they were suffering from typhus, were taken by American soldiers to Hillersleben. Manis Mizrachi, ${ }^{34}$ interviewed by David Boder, provided interesting details on the events following the liberation, in particular he said that his parents died and he was hosted by German families, who had been forced by Americans to provide former prisoners with food and shelter. As his parents before him, Mizrachi became ill with typhus and was hospitalised in Hillersleben. When he recovered, he weighed $42 \mathrm{~kg}$. A testimony on that event was given by Frank Towers, a soldier of the 30th Infantry Division, which ran into the train:

\footnotetext{
${ }^{33}$ Interview with Nino Barzilai. www.voices.itt.edu. (now https://voices.library.iit.edu/) [accessed on: 20.03.2019].

${ }^{34}$ Interview with Manis Misrachi. www.voice.itt.edu. (now https://voices.library.iit.edu/) [accessed on: 09.02.2019].
} 
In between Brunswick and Magdeburg was the city of Hillersleben, where there was a large German Luftwaffe airbase with many two-story barracks buildings for the Nazi German personnel who had recently been evicted by the 30th Infantry Division during the capturing of Hillersleben.

At this point, a small task force, led by the 743rd Tank Battalion, with infantrymen of the 119th Regiment, was mounted on these tanks. As they were forging ahead towards Magdeburg, they entered the small town of Farsleben, about $10 \mathrm{~km}$ north of Magdeburg, with the mission of clearing out all of the German soldiers who may be waiting there for us, and may have set up an ambush.

...Upon entering and capturing the village, no German soldiers were found who may have been intent on setting up an ambush when we appeared. However, the lead elements of the 743rd Recon discovered a long freight train on the railroad track, which had been guarded by several Nazi guards. The engine was standing ready with a full head of steam and awaiting orders as to where to go. The guards and the train crew fled the area as soon as they realized that they were well outnumbered, although they were rounded up in a short time. As the train was sitting idly by, while the train crew was awaiting orders and making a decision as to where to go, many of the occupants of some of the passenger cars had dismounted and were relaxing on the ground near the train.

This train, where about 2,500 Jews were, had left the Bergen-Belsen death camp some days earlier. Men, women and children, were all loaded into a few available railway cars, some passenger and some freight, but mostly the typical antiquated freight cars, termed as „40 and 8 ”, a WWI terminology. This meant that these cars could accommodate 40 men or 8 horses.

They were crammed into all available space and the freight cars were packed with about 60-70 of the Jewish Holocaust victims, with standing room only for most of them, so that they were packed in like sardines....

Some of these prisoners had dismounted from the passenger cars and were milling about near the train and relaxing, as best they could, under the watchful eyes of their Nazi guards. Those in the freight cars were still locked in the cars when discovered, but shortly they were released.

The men of the 743rd Tank Battalion and the 119th Regiment, who discovered this train, could not believe what they were seeing, nor what they had upon their hands at this moment. Upon speaking to some of those victims, a few of whom could speak a little English, they began to learn what they had uncovered. Each one had a slightly different story to tell, so there is no way of accurately knowing what the real story was. Now after 60 plus years, and having heard the stories from their parents, there is a good possibility that there may be some inaccuracies or exaggerations.

They immediately unlocked all of the freight cars and allowed these pathetic victims to be released and dismount from the cars and enjoy their first taste of freedom. Many were hesitant at first because they had been advised by their Nazi guards that, if and when they ever became prisoners of the Americans, they would be executed immediately. Little did they know what to expect at the hands of these savage Americans. ${ }^{35}$

Some of the survivors from the train, like Manis Mizrachi, Eva Button, Jacob Button, and Nino Barzilai, arrived in Paris in the shelters provided by the Joint Distribution Committee, where they were interviewed by David Boder in the summer of 1946. They remained in Paris waiting for visas, while others returned to Greece in June 1945. ${ }^{36}$

\footnotetext{
${ }^{35} \mathrm{http}: / /$ www.30thinfantry.org/holocaust.shtml [accessed on: 02.05.2019].

${ }^{36}$ World Jewish Congress London (London no. 130). List of Greeks (Jews) who were arrested in Athens on 25 Mar 1944 by the SS and deported on 2 Apr 1944. Now repatriated and registered in Brussels and Paris (some cases with dates of death) List dated 25 Jun 1945.
} 
Another group of Salonikan Jews was taken to Bergen Belsen during the evacuations. They were liberated by the British Army on 15 April 1945. Some of them returned to Greece passing through Bulgaria and stayed in a quarantine camp in Sidirokastro, close to the Bulgarian border, before returning to Saloniki. Others were taken to Sweden in July 1945 since 13 Greek names, five from Saloniki, can be found in the list of refugees sent there on 24 July. ${ }^{37} \mathrm{~S} / \mathrm{S}$ Kastelholm, one of the Swedish Red Cross' "White Ships", carried 400 survivors from Lübeck, Germany, to Stockholm's Frihamnen port. From there some of the refugees were transported to Ropsten sanitary facility and from there to the Epidemic Hospital at Roslagstull in Stockholm or the field hospital in Sigtuna.

Other Salonikans, who were liberated from Mauthausen or Ebensee, were kept there until 23 May 1945, when they were allowed by the Red Cross to leave; among them there was Isaak M. who was evacuated there on 25 January $1945 .^{38}$ 180 Greeks, among them Moshe H., survived Ebensee and decided to return to Greece through Italy on June 1945; they stayed for some months in the north where they met the Jewish Brigades. Moshe $\mathrm{H}$. changed his mind and decided to go to Palestine. He spent one year in a camp in southern Italy, then left from Genoa by boat, stopped at Cyprus and arrived in Palestine. In the ITS archives there is a document dated 21 May 1945 which specifies the names of Greek prisoners liberated in Ebensee and the relatives for whom they searched: Shlomo Venezia and Dario Gabbai, former Sonderkommando, and Heinz Kounio were among them. ${ }^{39}$

Women liberated from Ravensbrück and its subcamps almost immediately left the Russian zone and went to Americans. From there some returned to Greece passing through Bulgaria, like Erika Kounio Amariglio; others, like Lisa Pinhas, passed through Romania and in August 1945 arrived back in Greece (Pinhas, 2006). Some went to France and remained in Paris, like Rita Benmayor, or went to Belgium.

One of the DP camps to which many Salonikan Jews were transferred after the liberation was Feldafing, 20 miles southwest of Munich, originally a summer camp and a school for Hitler youth. It was established as a DP camp by the US Army on 1 May 1945, and it became the first all-Jewish DP camp. Jewish survivors were taken there after the liberation of camps and subcamps in Germany,

\footnotetext{
${ }^{37} \mathrm{http} / / /$ www.jewishgen.org/databases/Holocaust/0095_Bergen-Belsen-to-Sweden.html [accessed on: 02.05.2019]. The file is dated 14 July 1945. The collection contains information from records of the UNRRA (United Nations Relief and Rehabilitation Administration) European Regional Office. The official citation: United Nations Archives S-0523-0646, UNRRA, European Regional Office. The files are also available at the United States Holocaust Memorial Museum in Washington, DC [USHMM Acc. 1997.A. 0235, Reel 5].

${ }^{38}$ ITS Archives: 1 Incarceration Documents / 1.1 Camps and Ghettos / 1.1.26 Mauthausen Concentration Camp / 1.1.26.3 Individual Documents Regarding Male Detainees Mauthausen / Personal Files (male) - Concentration Camp Mauthausen Reference Code 01012603 oS

${ }^{39}$ Its Archives: Incarceration Documents / 1.1 Camps and Ghettos / 1.1.26 Mauthausen Concentration Camp / Liberation lists for detachment Ebensee, CC Mauthausen - (postwar compilation) Reference Code 8120400 Creation Date 1945-05-21 - 1945-09-30. O.C.C. 15/93 b- IV A2(F4-5/A) 68.
} 
initially mainly from the Dachau complex. The presence of Salonikans was recollected upon by Francesca Wilson, a British relief worker, who wrote about them in her work Aftermath (Wilson, 1947) and by Saul Sorrin, who worked for UNRRA and at the end of 1945 was sent to Neu Freimann Siedlung, a DP camp near Munich, Germany, to help Holocaust survivors.

We had also other groups which are less well-known. We had the Jews of Saloniki, who survived Dachau, Auschwitz, Dachau - Greek Jews that is. Very roughneck crowd, by the way. Saloniki was known for its roughneck community, they were stevedores, you know.I don't know whether it's a stereo[type]. That's what I heard. I haven't really studied the community. But, believe me, the people I saw were really tough. There was a lot of problems between them, by the way, and the Polish Jews. Violence between these two groups. So much so that Rabbi [David] de Sola Pool, the famous Sephardic rabbi from New York, had to fly over to try to deal with it. We had to move hundreds of Greek Jews out of one of the camps which was a Polish Jewish DP camp for their own safety, you know. They objected, and the major reason is that there was a good deal of business in that camp ... Competition frequently took a violent form. There was a camp in which they lived. It was called Feldafing. It was a large camp, three or four thousand people. And in that camp ... There was a very heavy black market.

\section{After some accidents:}

we decided that we would resettle - that's a term, by the way, which is a non-kosher term. It was in Yiddish or in German called umsiedlung, resettle these Greek Jews. We couldn't resettle five thousand Poles. So we tried to do it as nicely as possible to say, „Look, we're going to take you to this other place. Do your business there." But apparently that was not as lucrative. So the next thing I knew I had a telegram, was either from the States or from the UNRRA headquarters, asking what was going on. They'd received this telegram from Rabbi Pool, de Sola Pool, who's a patriarch of the Sephardic congregations in New York, the grand old man of a congregation on Fifth Avenue, personal friend of Franklin Roosevelt and other greats, saying he was coming over. What is this he's hearing? He's receiving reports that the same things that Hitler did to them were now being done all over again. They were being umgesiedlungt, resettled. We met. He came, he flew over, and we met and tried to explain that this was really something which was done because an alternative would have been violence. We finally managed to quiet the whole thing down. But the black marketeering, the economics, was given the vitality of the Jews, their need to reestablish when everything had been taken from them, it was an important part of their life, the economics. That is, living in this economic system which was separate from the above board economic system in postwar Germany. ${ }^{40}$

Leon M., after being deported to Auschwitz and Warsaw, arrived in Dachau on 6 August 1944. He was transferred to a Waldlager in Müldorf where he remained for 5 months, from November 1944 to April 1945. After the liberation he was taken to Feldafing where he met his future wife, who had been transferred there from

\footnotetext{
${ }^{40}$ About the situation of Greek Jews in Feldafing see also JDC archives: Letter from Charles Passman to AJDC Munich

Item ID: 2059654. Date: 9/28/1948. Author: Passman, Charles. Reference Code: G 45-54 / 4 / 8 / 49 / GER.794

In Folder: Germany (U.S. Zone): Feldafing Camp. 1948. Search in Collection: 1945-1954 Geneva Collection. https://archives.jdc.org [accessed on: 02.01.2020].
} 
Bergen Belsen. They had their first son there in 1946, tried to go to Palestine but had to return to Feldafing where their second son was born in 1950. From the documents available at the ITS archives we can see that many Salonikan Jews followed the same path as Leon, i.e. of a transfer from Auschwitz to Warsaw, then Dachau (Müldorf) and Feldafing. Beppo and Moise, for instance, left from there for Haifa but returned to Germany in 1950 and remained in the Fohrenwald DP camp waiting for their visas for Canada. ${ }^{41}$ One can find more information about Salonikan Jews in Feldafing and other DP camps from a letter written to the Central Committee of Jewish Communities in Greece by the Union des Juifs Sépharadiques Grecs en Allemagne from Feldafing on 15 December $1946 .{ }^{42}$ The president of the Union provided the Central Committee with information about Greek Jews there. He wrote that their number was not as high as that of Jews from other countries and sent a list with their names. From August 1945 there were Salonikans in Feldafing, housed in Block 4/b. In December 1946 he wrote that there were also 37 Greeks, not specifying if from Saloniki, in Landsberg, at least 4 in Bamberg, 3 at the tubercolosis Sanatorium in Gauting, 1 in the hospital in St. Ottilien, 2 in Forenwald, in Munchen, and in Nuremberg. It is also interesting that Azriel summarised the possible destinations for emigration of the people he knew inside the camp: 10 of them had relatives in the USA, but could not leave because of a quota for Greeks; about 20 wished they could go to Palestine but did not have the permits; 15 wanted to return to Greece to search for their relatives; others did not know where to go.

The situation in other DP camps was similar. Many Greeks ended up in camps in Italy, such as Santa Cesarea Terme, before getting to Greece or Palestine in the following months and years. According to what Azriel wrote in 1946, they felt like a boat without a captain or a compass.

\section{CONCLUSION}

The fate of the Jews from Saloniki during the Holocaust may well represent the complexity of the event in terms of it extent and the diversity of experiences. Even though the persecution, deportation and extermination of Jews was planned and

\footnotetext{
${ }^{41}$ ITS Archives: Registrations and Files of Displaced Persons, Children and Missing Persons / 3.2 Relief Programs of Various Organizations / 3.2.1 IRO "Care and Maintenance" Program / CM/1 files from Germany, A-Z Reference Code Number of documents 916266. https://arolsen-archives. org [accessed on: 15.02.2020].

423 Registrations and Files of Displaced Persons, Children and Missing Persons / 3.1 Evidence of Abode and Emigration / 3.1.1 Registration and Care of DPs inside and outside of Camps / List of Greek Jews in the camp Feldafing 15.12.1946 in various locations. Reference Code 421000. Number of documents 11 - Immediate source of acquisition or transfer World Jewish Congress London (London $n^{\circ}$ 1038). https://arolsen-archives.org [accessed on: 15.02.2020].
} 
organised by Nazis following a Europewide plan, this was implemented through different variables: time, place, the geographical origins of deportees and their language skills, and the phase of the war. The victims of the persecution dealt with difficult experiences of different type which represented the parts of an overall plan. The personal documents (interviews, testimonies, and accounts), studied together with official archival documents show that the fortunes of Salonikan Jews were paradigmatic. Microhistorical studies combined with macrohistorical ones contribute significantly to a better understanding of the Holocaust and its impact on groups as well as on individuals.

\section{REFERENCES}

ANTONIOU, G. and MOSES, A. D. (eds.) (2018), The Holocaust in Greece. Cambridge: Cambridge University Press. https://doi.org/10.1017/9781108565776

BAUER, Y. (1983), 'The Death-Marches, January-May, 1945', Modern Judaism, 3 (1), pp. 1-21. www.jstor.org/stable/1396164 [accessed on: 12.01.2020]. https://doi.org/10.1093/mj/3.1.1

BENBASSA, E. (2014), Salonique, ville juive, ville ottomane, ville grecque, Paris: CNRS edition.

BLATMAN, D. (2011), The Death Marches - The Final Phase of the Nazi Genocide, Boston: Harvard University Press. https://doi.org/10.2307/j.ctvjnrvg1

BLATMAN, D. (2014), “"Why Didn't They Mow Us Down Right Away?». The Death March Experience in Survivors'testimonies and Memoirs', [in:] GODA, N. J. W., Jewish Histories of the Holocaust: New Transnational Approaches, 19, Making Sense of History, New York: Berghan Books.

BODER, D. (1949), I Did Not Interview The Dead, Urbana: University of Illinois Press. https://doi. org/10.1037/13245-000

BOWMAN, S. (ed.) (2002), The Holocaust in Salonika - Eyewitness Account, New York: Sephardic House and Bloch Publishing Co.

BOWMAN, S. (2009), The Agony of Greek Jews, 1940-1945, Stanford: Stanford University Press. https://doi.org/10.11126/stanford/9780804755849.001.0001

BOWMAN, S. (2014), 'Greek Responses to the Nazis in the Mountains and in the Camps', [in:] PATRICK, H. (ed.), Jewish Resistance against the Nazis, Washington: Cua Press, pp. 161-184. https://doi.org/10.2307/j.ctt7zswcf.12

CESARANI, D. and SUNDQUIST, E. (ed.) (2012), After the Holocaust-Challenging the Myth of Silence, New York: Routledge. https://doi.org/10.4324/9780203803141

CHARMATZ, K. (2003), Nightmares: Memoirs of the years of Honor under Nazi Rule in Europe (1939-1945), New York: Syracuse University Press.

COPPOLA, S. and PERI, M. (2007), 'Sugli ebrei di Salonicco', Studi Storici, 48 (4), pp. 1155-1164. CZECH, D. (1990), The Auschwitz Chronicle: 1939-1945, New York: Holt.

DAWIDOWICZ, L. S. (1975), The War Against the Jews 1933-1945, New York: Bantam Books.

DEBLINGER, R. (2012), 'P. Boder - Holocaust Memory in Displaced Persons Camps', [in:] CESARANI, D. and SANDQUIST, E. J. (eds.), After the Holocaust: Challenging the Myth of Silence, New York: Routledge, pp. 191-208.

FRANCO, M. (2004), 'Diversão balcânica: os israelitas portugueses de Salónica', Análise Social, XXXIX (170), pp. 119-147.

FRANCO, M. (2006), 'O Estado Novo e os Judeus. Os Portugueses de Salónica', Estudos Judaicos, Revista da Associação Portuguesa de Estudos Judaicos, 9, pp. 14-22.

GILBERT, M. (2014), The Holocaust - The Human Tragedy, London: RosettaBooks LLC. 
GREIF, G. (2005), We wept without tears - Testimonies of the Jewish Sonderkommando from Auschwitz, New Haven: Yale University Press. https://doi.org/10.12987/yale/9780300106510.001.0001

HANDELI, Y. (1993), A Greek Jew from Salonica Remembers, New York: Herzl.

HILLBERG, R. (1985), La distruzione degli Ebrei d'Europa, Torino: Einaudi.

JACOBS, B. (1995), The Dentist of Auschwitz, Lexington: The University Press of Kentucky.

KARATZOGLOU, Y. (2014), Ho aphanismós ton Thessalonikeion Evraion tes Gallias 1942-1944,

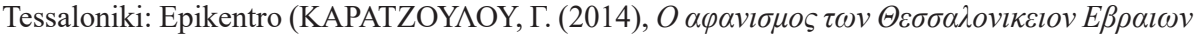

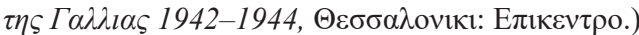

KOSSO, E. (2004), 'The Gesiówka Story - A Little Known Page of Jewish History Fighting', Yad Vashem Studies, 32, pp. 323-350.

KOUNIO AMARIGLIO, E. (1998), From Thessaloniki to Auschwitz and Back, London: Valentine Mitchell.

KRAKOWSKI, S. (1989), 'The death marches in the period of the evacuation of the camps', [in:] MARRUS, M. R., The Nazi Holocaust - Part 9: The end of the Holocaust, Berlin: De Gruyter.

KRANZ, T. (2007), The Extermination of Jews at Majdanek Concentration Camp, Lublin: Państwowe Muzeum na Majdanku.

LANG, H. J. (2004), Die Namen der Nummern: wie es gelang, die 86 Opfer eines NS-Verbrechens $z u$ identifizieren, Hamburg: Hoffmann und Campe.

LANG, H. J. (2011), Die Frauen von Block 10: Medizinische Versuche in Auschwitz, Hamburg: Hoffmann und Campe.

LANGBEIN, H. (2004), People in Auschwitz, Chapel Hill: University of North Carolina Press.

LEVI, P. (1958), Se questo è un uomo, Torino: Einaudi.

LEWKOWICZ, B. (2006), The Jewish community of Salonika - History, Memory, Identity, London/ Portland: Valentine Mitchell.

LIKIERNIK, S. (2001), By Devil's Luck: A Tale of Resistance in Wartime Warsaw, Edinburgh: Mainstream Publishing Company.

MATSAS, M. (1997), The Illusion of Safety: The Story of the Greek Jews During World War II, New York: Pella Publishing Company.

MAZOWER, M. (1995), Inside Hitler's Greece - The Experience of Occupation 1941-1944, New Heaven and London: Yale University Press.

MAZOWER, M. (2004), Salonicco, città di fantasmi, Milano: Garzanti.

MEGHNAGI, D. (2005), Ricomporre l'infranto. L'esperienza dei sopravvissuti alla Shoah, Venezia: Marsilio.

MOLHO, M. (1973), In Memoriam, Thessalonique: Communauté Israélite de Thessalonique.

MULLER, B. (2014), 'Translating Trauma: David Boder's 1946 Interviews with Holocaust Survivors', Translation and Literature, 23 (2), pp. 257-271. https://doi.org/10.3366/tal.2014.0155

NIEWYK, D. (1998), Fresh Wounds: Early Narratives of Holocaust Survival, Chapel Hill: University of North Carolina Press.

NOVITCH, M. (1977), Le passage des barbares: contribution a l'histoire de la déportation et de la résistance des juifs grecs, Paris: Presses du Temps Présent.

PHOTINI, T. (Hellenic Ministry of Foreign Affairs) (2009), Greeks in Auschwitz-Birkenau, (translation by Alexandra Apostolides), Athens: Papazisis Publishers S.A.

PINHAS, L. (2006), Récit de l'enfer Manuscrit en français d'une Juive de Salonique déportée, Paris: Edition Le Manuscrit.

REESE, L. (2006), Auschwitz - I Nazisti e la soluzione finale, Milano: Arnoldo Mondadori Editore.

REILLY, J. (1998), Belsen: The Liberation of a Concentration Camp, London: Routledge Twentieth Century European History Series.

REILLY, J., CESARANI, D., KUSHNER, T. and RICHMOND, C. (eds.) (1997), Belsen in History and Memory, London: Frank Cass. 
ROSEN, A. (2010), The Wonder of Their Voices - The 1946 Holocaust Interviews of David Boder, New York: Oxford University Press.

ROZEN, M. (2005), 'Jews and the Greeks Remember Their Past: The Political Career of Tzevi Koretz (1933-1943)', Jewish Social Studies, 12 (1), pp. 111-166. https://doi.org/10.1353/ jss.2006.0007

SARFATTI, M. (2012), 'L'evacuazione nel 1943 da Salonicco degli ultimi ebrei italiani e degli ebrei italiani 'provvisori': contesto, questioni e numeri', [in:] ZORATTINI, P., LUZZATI, M. and SARFATTI, M. (eds.) Studi sul mondo sefardita in memoria di Aron Leoni, Firenze: Olschki, pp. 251-276.

STONE, D. (2015), The Liberation of the Camps: The End of the Holocaust and Its Aftermath, London: Yale University Press.

TOMAI, P. (Hellenic Ministry of Foreign Affairs) (2009), Greeks in Auschwitz-Birkenau, Athens: Papazisis Publishers S.A.

VAN PELT, R. J. and DWORK, D. (1996), Auschwitz 1270 To the Present, London: Yale University Press.

VRBA, R. and WETZLER, A. (1944), The Auschwitz Protocol. The Vrba-Wetzler Report (Transcribed from the original O.S.I. report of the US Department of Justice \& the War Refugee Board Archives).

WACHSMAN, N. (2015), KL A history of The Nazi Concentration Camps, London: Little, Brown Book Group.

WEINDLING, P. (2014), Victims and Survivors of Nazi Human Experiments: Science and Suffering in the Holocaust, London: Bloomsbury.

WILSON, F. (1947), Aftermath, London: Penguin Books.

ZEZZA, S. (2018), 'Taken from a Distant Country', Sephardic Horizons, 8 (3-4).

ZEZZA, S. (2020), 'We Are a Strict Iron Group: from Salonika to Warsaw via Auschwitz', Sephardic Horizons, 10 (3-4).

\section{WEBSITES}

http://buchenwald.de [accessed on: 06.02.2019]

$\mathrm{http} / / /$ collections.ushmm.org [accessed on: 19.03.2019]

$\mathrm{http}: / /$ holocaust.umd.umich.edu/shlanger/ [accessed on: 10.01.2019]

http://HolocaustResearchProject.org [accessed on: 10.01.2019]

http://voices.itt.edu (now https://voices.library.iit.edu/) [accessed on: 09.02.2019]

http://wisconsinhistory.org/HolocaustSurvivors/Moshe.asp [accessed on: 05.05.2019].

http://www.30thinfantry.org/holocaust.shtml [accessed on: 02.05.2019]

http://www.jewishgen.org/databases/Holocaust/0095_Bergen-Belsen-to-Sweden.html [accessed on: 02.05.2019]

https://archives.jdc.org [accessed on: 02.01.2020].

https://collections.arolsen-archives.org [accessed on: 02.03.2019]

https://deportation.yadvashem.org [accessed on: 01.02.2019]

https://jstor.org/stable/1396164 [accessed on: 12.01.2020]

https://testimonies.yadvashem.org/index.html [accessed on: 20.06.2017]

https://www.thebreman.org/Research/Southern-Jewish-Archives/Oral-Histories [accessed on:

10.04.2019]

https://www.zapisyterroru.pl//Content/4070/Brewda_Alina_2_pl [accessed on: 01.04.2019] 